\title{
Ecological characterization of dredged and non-dredged bivalve fishing areas off south Portugal
}

\author{
L. Chícharo** ${ }^{\ddagger}$ A. Chícharo*, M. Gaspar ${ }^{\dagger}$, F. Alves* and J. Regala* \\ *Universidade do Algarve, UCTRA/CGMAR, Campus de Gambelas, P-8000 810 Faro, Portugal. \\ ${ }^{\dagger}$ Instituto de Investigação das Pescas e do Mar, CRIPSul, Avenida 5 de Outubro, s/n, 8700-305 Olhão, Portugal. \\ ${ }^{\ddagger}$ Corresponding author, e-mail: lchichar@ualg.pt
}

\begin{abstract}
Macro and meiobenthic communities of two fishing areas (Vilamoura and Lagos) in the western part of south Portugal (Algarve coast) were analysed. Both locations had been under severe dredge-fishing impact until four years previously. Vilamoura has since continued to be dredged, while fishing activity in Lagos was stopped in 1995 as a response to overfishing. For each location, three replicate areas were analysed at depths of 7-9 m. In each of these areas, 18 quadrats for macrofauna and 12 cores for meiofauna were randomly sampled by SCUBA divers during September 1999. The Shannon-Weiner diversity index was higher for meiofauna in the fished area, whereas macrofauna diversity was higher in the recently nonfished area. Bray-Curtis dissimilarity between the two areas was $87.82 \%$. Major differences were found between Ampeliscidea, Amphiura mediterranea, Spisula solida, Haustoriidae, Nemertinea and Diogenes pugilator populations at the two sites. There was higher abundance but lower biomass of potential macrofaunal scavengers in the fished area, and carnivore biomass was also higher in this area. Deposit-feeders dominated meiofauna abundance in both study areas. The community structure of the continuously fished area was dominated by small, opportunistic, short-lived species while the community structure of the recently non-fished area was dominated by more fragile and long-living sessile organisms.
\end{abstract}

\section{INTRODUCTION}

Commercial fishing has one of the greatest impacts on the marine benthic ecosystem, as benthic habitats are disturbed when fishing gear is dragged across the sea-floor. The environmental effects of shellfish dredging have received special attention throughout the world during recent decades (e.g. Caddy, 1973; Conner \& Simpson, 1979; Eleftheriou \& Robertson, 1992; Hall et al., 1993; McLoughlin et al., 1991; Dare et al., 1993; Jennings \& Kaiser, 1998; Gilkinson et al., 1999; Hall-Spencer \& Moore, 2000). In Portugal, a dredge fishery has exploited clam populations since 1969, and currently has great socioeconomic importance. Target species are Spisula solida, Donax trunculus, Venus striatula, Pharus legumen and Ensis siliqua. In the Algarve (south Portugal), 57 bivalve fishing boats with a maximum 100.8 HP are licensed. The dredges used are heavy iron structures with a net bag and a toothed lower bar at the mouth. The teeth are $10-50 \mathrm{~cm}$ long, depending upon the target species, and act as a rake when the dredge is dragged over the sea bottom (Gaspar, 1996).

Despite most studies having shown that it is possible to detect short-term changes in community structure in response to fishing disturbance (e.g. de Groot, 1984; Currie \& Parry, 1999; Kaiser \& Spencer, 1996), longterm changes (see Frid et al., 1999) are more difficult to evaluate and are consequently scarce in the published literature. When an area has been continuously fished for several decades, it can be difficult to distinguish between changes in the community caused by fisheries disturbance and those caused by natural phenomena (Currie \& Parry, 1996). Kaiser et al. (1998) have referred to the importance of evaluating the ecological relevance of fishing disturbance vs natural perturbations, which will vary between different habitats. To analyse these long-term effects, comparisons are usually conducted between areas that are fished and non-fished, but interpretation can be difficult as non-fished areas usually differ physically from commercial fishing grounds. A variant on this approach is to examine fishing effects in an area that has been closed to fishing (Tuck et al., 1998; Bradshaw et al., 1999).

Traditionally, bivalve fishing grounds have been overexploited, and it is necessary to take measures to mitigate reductions in target species abundance. In the Algarve region these measures include TACs, minimum mesh size (25 mm) and closure periods (from 1 May until 15 June). This closure aims to protect spawning individuals. In heavily exploited areas, larger periods of closure could be needed. However, the complete closure of an entire fishing area can have high socio-economic impact. As an alternative, temporary closure of fishing sub-areas to allow their recovery can be a useful tool for fishery management.

In this study, we analysed a recently four-years non-fished area (Lagos) with a continuously fished area (Vilamoura), and differences in benthic macrofaunal and meiofaunal diversity, abundance, and biomass are discussed, as well as in the relative importance of feeding groups.

\section{MATERIALS AND METHODS}

\section{Study site}

The Algarve coast (south Portugal) extends from Cabo São Vicente $\left(08^{\circ} 59^{\prime} \mathrm{W}\right)$ in the west to the border with Spain in the east $\left(07^{\circ} 24^{\prime} \mathrm{W}\right)$ (Figure 1). The continental shelf off the Algarve is narrow. Both study sites - the 


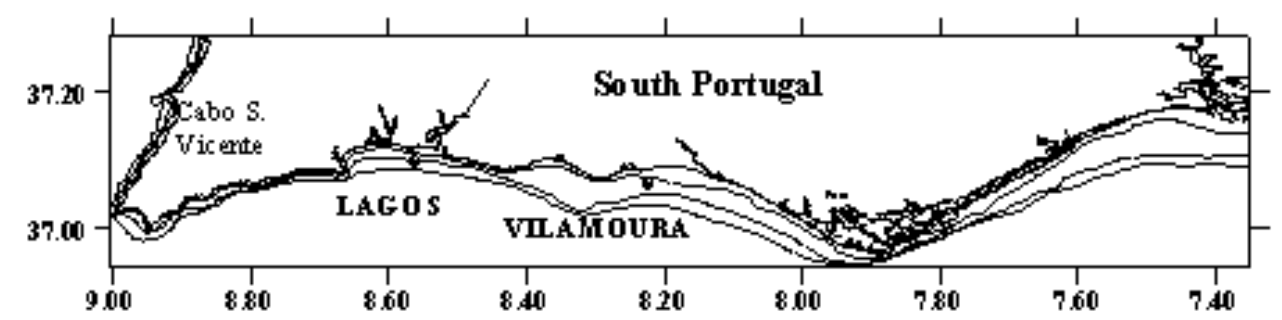

Figure 1. The south Portugal (Algarve) coast, showing location of the studied areas: Vilamoura (continuously fished area) and Lagos site (recently non-fished area).

continuously fished area, Vilamoura $\left(37^{\circ} 05^{\prime} \mathrm{N} 08^{\circ} 02^{\prime} \mathrm{W}\right)$, and the recently non-fished area, Lagos $\left(37^{\circ} 08^{\prime} \mathrm{N}\right.$ $\left.08^{\circ} 06^{\prime} \mathrm{W}\right)$ - are located in the western part of the Algarve coast. Drift currents $\left(\sim 0.25-0.50 \mathrm{~m} \mathrm{~s}^{-1}\right.$; Fiúza, 1983) run westwards parallel to the shore at $30 \mathrm{~m}$ depth and predominate over tidal currents. The two locations have similar hydrologic (water temperature, salinity, $\mathrm{pH}$, etc.), depth (7 to $9 \mathrm{~m}$ ) and sea bottom characteristics (sandy sediment in both areas) (Moita, 1986; Dias, 1987; Teixeira, 2000; Vieira et al., 2000). Due to the low depth of the sampling sites, changes in sediment characteristics (granulometry, organic content, etc.) may occur as a consequence of weather conditions.

\section{Experimental design and sampling}

Samples were collected at 7-9 m water depth during September 1999. At both study sites, three areas $(\sim 50 \times 50 \mathrm{~m})$ were analysed. At each of these replicated areas 18 quadrats $\left(0.0625 \mathrm{~m}^{2} \times 0.15 \mathrm{~m}\right)$ for macrofauna, and 12 corers $\left(0.001 \mathrm{~m}^{2} \times 0.15 \mathrm{~m}\right)$ for meiofauna were randomly placed and sampled by SCUBA divers. The sediment in the area of the quadrats was carefully dug with a spade to $1-\mathrm{mm}$ mesh bags. Corers samples were sealed in situ, after collection. The number of replicates to be used was determined after considering a previous study in the same areas performed by Chicharo et al. (2000), and following Elliot (1977):

$\mathrm{N}=\mathrm{s}^{2} \times(\mathrm{m} \times \mathrm{D})^{-2}$

where: $\mathrm{N}$ is the number of replicates, $\mathrm{s}$ is the sample variance, $\mathrm{m}$ is the mean density per sample unit, and $\mathrm{D}$ is the sample precision (accuracy $=\mathrm{SE} / \mathrm{m}$ ). Because spatial aggregation of benthic organisms changes over time and space, variance is highly sensitive to mean density (Downing, 1989). To reduce this variability, sampling variance was calculated from the empirical algorithm for marine benthos by Vezina (1988):

$\mathrm{s}^{2}=1.641 \times \mathrm{m}^{1.219}$

where $m$ is the mean density per sample. Macrofauna samples were sieved immediately after collection, on the surface, through 1-mm mesh bags.

\section{Laboratory procedures}

Meiofauna samples were sieved through a $150-\mu \mathrm{m}$ mesh. Both macrofauna and meiofauna samples were preserved in $70 \%$ ethanol. Organisms were sorted to the lowest possible taxonomic level and counted. Ash free dry weight was calculated for bivalve biomass determinations. These animals were dried at $60^{\circ} \mathrm{C}$ until constant weight was reached (at least $48 \mathrm{~h}$ ) and then burned at $450^{\circ} \mathrm{C}$ for three hours in a muffle-furnace. Linear measurements of the less abundant species of bivalves, gastropods and echinoderms were recorded and used for macrofauna biomass calculations, following Gamito (1994) and Sprung (1993, 1994a). Meiofaunal biomass was calculated following Sprung (1994b), Banse (1982) and Knox (1986).

\section{Data analysis}

Species diversity was calculated using the ShannonWiener index, H' (Daget, 1979). Significant differences in meiofaunal and macrofaunal diversity and trophic groups between areas were analysed using one-way analysis of variance (ANOVA) $(F$-test $)(P<0.05)$, performed with the Statistic V.5 software package. The specific contribution of macrofauna species to the observed differences in Bray-Curtis dissimilarity between sites was analysed using the SIMPER routine ('Similarity percentages') of the PRIMER (Plymouth Routines in Multivariate Ecological Research) software package (Clark \& Warwick, 1994). The selected value for the percentage cut-off was 100.0. Analyses were carried out using squareroot transformation to normalize the data.

Categorization of macrofauna (Table 1) and meiofauna (Table 2) into trophic groups was based on Feder (1981), Commito \& Shrader (1985), Rield (1986), Bemvenuti (1994), Gamito (1994), McKillup \& McKillup (1994), Sprung (1993, 1994a), Fish \& Fish (1996) and Skoeld \& Rosenberg (1996). We considered carnivores and omnivores to be potential scavengers, as proposed by Lindeboom \& de Groot (1998). Many species can exhibit different modes of feeding in particular situations, depending, for instance, on their nutritional condition. Taxa were assigned to one trophic group according to the most usual (more frequent) feeding habit they exhibit (based on literature references). Thus, macrofauna taxa that may act as both suspension-feeders and depositfeeders were considered to be preferentially suspensionfeeders and not deposit-feeders. Also, as it is difficult to differentiate meiofaunal scavengers from deposit-feeders, we only consider a deposit-feeding group and a carnivorous group. Herbivores include grazers, some of which can be detritivores. 
Table 1. Trophic categorization of macrofauna taxa at the continuously fished (Vilamoura) and the recently non-fished (Lagos) study areas. For calculations purposes taxa were assigned to the most common feeding habit (the first listed, when several indicated).

\begin{tabular}{clll}
\hline TAXA & & Occurrence \\
\cline { 2 - 3 } MACROFAUNA & Feeding habits & Lagos & Vilamoura \\
\hline
\end{tabular}

Nemertinea n.id.

Sipuncula n.id.

Aphroditidae

Capitellidae

Cirratulidae

Eunicidae

Phyllodocidae

Glyceridae

Hesionidae

Magelonidae

Maldanidae

Nephtydidae

Nereidae

Opheliidae

Orbiniidae

Oweniidae

Sabellaridae

Sabellidae

Spionidae

Terebellidae

Poliplacophora n.id.

Abra alba

Abra ovata

Acanthocardia aculeata

Acanthocardia spinosa

Acanthocardia tuberculata

Acanthocardia sp.

Anomia ephippium

Chamelea gallina

Callista chione

Clausinella brongniartii

Corbula gibba

Donax semistriatus

Donax trunculus

Donax variegatus

Donax vittatus

Dosinea exoleta

Ensis ensis

Ensis siliqua

Pharus legumen

Loripes lucinalis

Lutraria anguistor

Lyonsia norwergica

Mactra corallina

Mactra glauca

Mesalia brevialis

Modiolus modiolus

Musculus costulatus
Nemertina

Sipuncula

Annelida

Polychaeta

SC, C

DF

$\times$

$\mathrm{SF}, \mathrm{DF} \quad x$

$\mathrm{DF} x$

DF

DF

C

SF

C

SF, DF

$\mathrm{SC}, \mathrm{C}$

C, SC, DF

DF

DF

SF

SF

$\mathrm{SF}$

SF, DF

DF

Mollusca

Polyplacophora

HV

Bivalvia

SF

SF, DF

SF, DF

SF

SF

$\mathrm{SF}$

SF

$\mathrm{SF}$

SF, DF

$\mathrm{SF}$

SF

DF

SF, DF

SF

SF

SF

SF

SF, DF

$\mathrm{SF}$

SF 
Table 1. (Continued).

\begin{tabular}{|c|c|c|c|c|}
\hline & \multirow{2}{*}{$\frac{\text { TAXA }}{\text { MACROFAUNA }}$} & \multirow[b]{2}{*}{ Feeding habits } & \multicolumn{2}{|c|}{ Occurrence } \\
\hline & & & Lagos & Vilamoura \\
\hline Ostrea edulis & & $\mathrm{SF}, \mathrm{DF}$ & & $\times$ \\
\hline Pandora sp. & & $\mathrm{SF}, \mathrm{DF}$ & $\times$ & \\
\hline Pecten sp. & & $\mathrm{SF}, \mathrm{DF}$ & $x$ & \\
\hline Petricola lithophaga & & $\mathrm{SF}, \mathrm{DF}$ & & $\times$ \\
\hline Pharus legumen & & $\mathrm{DF}$ & $x$ & \\
\hline Scrobicularia plana & & $\mathrm{SF}, \mathrm{DF}$ & $x$ & \\
\hline Spisula elliptica & & $\mathrm{SF}$ & & $x$ \\
\hline Spisula solida & & $\mathrm{SF}$ & & $x$ \\
\hline Tellina tenuis & & $\mathrm{SF}, \mathrm{D}$ & & $x$ \\
\hline Tellina incarnata & & $\mathrm{SF}, \mathrm{D}$ & & $x$ \\
\hline \multirow[t]{2}{*}{ Thracia pubescens } & & $\mathrm{SF}, \mathrm{DF}$ & & $x$ \\
\hline & Gastropoda & & & \\
\hline Bulla striata & & $\mathrm{HV}, \mathrm{DF}$ & $x$ & \\
\hline Calyptraea chinensis & & $\mathrm{SC}, \mathrm{C}, \mathrm{DF}$ & & $x$ \\
\hline Cymbium olla & & DF & & $x$ \\
\hline Gibberula miliaria & & $\mathrm{HV}, \mathrm{DF}$ & $x$ & $x$ \\
\hline Natica prietoi & & $\mathrm{SC}, \mathrm{C}$ & $x$ & \\
\hline \multirow[t]{2}{*}{ Turritella communis } & & $\mathrm{SF}$ & $x$ & \\
\hline & $\begin{array}{l}\text { Crustacea } \\
\text { Cirripedia }\end{array}$ & & & \\
\hline \multirow[t]{2}{*}{ Balanus perforatus } & & $\mathrm{SF}$ & & $x$ \\
\hline & Ostracoda & & & \\
\hline \multirow{2}{*}{ Ostracoda n.id. } & & $\mathrm{HV}, \mathrm{DF}$ & $x$ & \\
\hline & Cumacea & & & \\
\hline \multirow[t]{2}{*}{ Pseudocuma longicornis } & & DF & $x$ & \\
\hline & Tanaidacea & & & \\
\hline \multirow[t]{2}{*}{ Apseudes latreillei } & & DF & $x$ & \\
\hline & Isopoda & & & \\
\hline Eurydice pulchra & & $\mathrm{C}$ & & $\times$ \\
\hline \multirow[t]{2}{*}{ Isopoda n.id. } & & $\mathrm{HV}, \mathrm{DF}$ & $\times$ & $x$ \\
\hline & Amphipoda & & & \\
\hline Ampeliscidae & & $\mathrm{HV}, \mathrm{DF}$ & & $\times$ \\
\hline Podoceridae & & $\mathrm{HV}, \mathrm{DF}$ & $x$ & $x$ \\
\hline \multirow[t]{3}{*}{ Haustoriidae } & & $\mathrm{HV}, \mathrm{DF}$ & $x$ & $x$ \\
\hline & Decapoda & & & \\
\hline & Natantia & & & \\
\hline Processa parva & & $\mathrm{SC}, \mathrm{C}$ & $x$ & $x$ \\
\hline \multirow[t]{2}{*}{ Crangon crangon } & & $\mathrm{SC}, \mathrm{C}$ & $x$ & $x$ \\
\hline & Raptantia & & & \\
\hline Crangon crangon & & $\mathrm{SC}, \mathrm{C}$ & $x$ & $x$ \\
\hline Diogenes pugilator & & $\mathrm{SC}, \mathrm{C}$ & & $x$ \\
\hline Liocarcinus pusillus & & $\mathrm{SC}, \mathrm{C}$ & & $x$ \\
\hline Parthenope massena & & $\mathrm{SC}, \mathrm{C}$ & & $x$ \\
\hline Pirimela denticulata & & $\mathrm{SC}, \mathrm{C}$ & & $x$ \\
\hline \multirow[t]{3}{*}{ Thia scutellata } & & $\mathrm{SC}, \mathrm{C}$ & & $\times$ \\
\hline & Echinodermata & & & \\
\hline & Asteroidea & & & \\
\hline \multirow[t]{2}{*}{ Astropecten irregularis } & & $\mathrm{C}$ & & $x$ \\
\hline & Ophiuroidea & & & \\
\hline Amphiura mediterranea & & $\mathrm{SF}$ & $\times$ & $x$ \\
\hline Ophiopsila annulosa & & $\mathrm{SC}, \mathrm{C}$ & & $x$ \\
\hline \multirow{2}{*}{ Ophiura texturata } & & $\mathrm{SC}$ & $x$ & $x$ \\
\hline & Echinoidea & & & \\
\hline Echinocardium cordatum & & DF & $x$ & $\times$ \\
\hline \multirow[t]{2}{*}{ Psamechinus miliaris } & & $\mathrm{SC}$ & & $x$ \\
\hline & Hemichordata & & & \\
\hline Branchiostoma lanceolatum & & $\mathrm{SF}$ & $\times$ & $\mathrm{x}$ \\
\hline
\end{tabular}

DF, deposit-feeder; SF, suspension-feeder; C, carnivore; HV, herbivore; SC, scavenger. 
Table 2. Trophic categorization of meiofauna taxa at the continuously fished (Vilamoura) and the recently non-fished (Lagos) areas. For calculations purposes taxa were assigned to the most common feeding habit (the first listed, when several indicated).

\begin{tabular}{|c|c|c|c|c|}
\hline & \multirow{2}{*}{$\frac{\text { TAXA }}{\text { MEIOFAUNA }}$} & \multirow[b]{2}{*}{ Feeding habits } & \multicolumn{2}{|c|}{ Occurrence } \\
\hline & & & Lagos & Vilamoura \\
\hline & Plathelminthes & & & \\
\hline \multirow[t]{2}{*}{ Turbellaria n.id. } & & $\mathrm{C}$ & $x$ & \\
\hline & Tartigrada & & & \\
\hline \multirow[t]{2}{*}{ Tartigrada n.id. } & & ? & $x$ & \\
\hline & Nematoda & & & \\
\hline \multirow[t]{2}{*}{ Nematoda n.id. } & & DF & $x$ & $x$ \\
\hline & Nemertina & & & \\
\hline \multirow[t]{2}{*}{ Nemertinea n.id. } & & $\mathrm{C}$ & $x$ & $x$ \\
\hline & Annelida & & & \\
\hline \multirow[t]{2}{*}{ Polychaeta n.id. } & & $\mathrm{C}, \mathrm{SF}, \mathrm{DF}$ & $x$ & $x$ \\
\hline & Mollusca & & & \\
\hline Bivalvia n.id. & & $\mathrm{SF}, \mathrm{DF}$ & $x$ & $x$ \\
\hline \multirow[t]{2}{*}{ Gastropoda n.id. } & & $\mathrm{HV}, \mathrm{DF}, \mathrm{C}$ & $x$ & \\
\hline & Crustacea & & & \\
\hline Ostracoda n.id. & & $\mathrm{HV}, \mathrm{DF}$ & $x$ & $x$ \\
\hline Copepoda n. id. & & $\mathrm{HV}$ & $x$ & $x$ \\
\hline Isopoda n. id. & & $\mathrm{HV}, \mathrm{DF}$ & $x$ & $x$ \\
\hline Amphipoda n.id. & & $\mathrm{HV}, \mathrm{DF}$ & $x$ & \\
\hline Cumacea n.id. & & DF & $x$ & \\
\hline
\end{tabular}

DF, deposit-feeder; SF, suspension-feeder; C, carnivore; HV, herbivore; SC, scavenger.

\section{RESULTS}

\section{Benthic communities}

The number of macrofaunal taxa found at the two study sites was 44 and 59 at Vilamoura and Lagos, respectively. Owing to difficulties in specific identification of meiofauna taxa, only nine different taxa were identified in the fished area and 15 in the recently non-fished area. The mean abundance of macrofauna was higher in the recently non-fished area, $12.198 \pm 4.439$ ind $\mathrm{m}^{-2}$, than in the fished area, $4.006 \pm 1.328$ ind $\mathrm{m}^{-2}$. Similarly, mean meiofauna abundance was higher in Lagos, 49,216.67 $\pm 43,975.9$ ind $\mathrm{m}^{-2}$, than in Vilamoura, 41,638 $\pm 34,594.15$ ind $\mathrm{m}^{-2}$. However, mean biomass of macrofauna was higher in the fished area, $0.648 \pm 0.558 \mathrm{~g} \mathrm{~m}^{-2}$, than in the non-fished area, $0.612 \pm 0.343 \mathrm{~g} \mathrm{~m}^{-2}$. In contrast, mean biomass of meiofauna was higher in Lagos, $4.906 \pm 4.663 \mathrm{~g} \mathrm{~m}^{-2}$, than in Vilamoura, $0.128 \pm 0.008 \mathrm{~g} \mathrm{~m}^{-2}$.

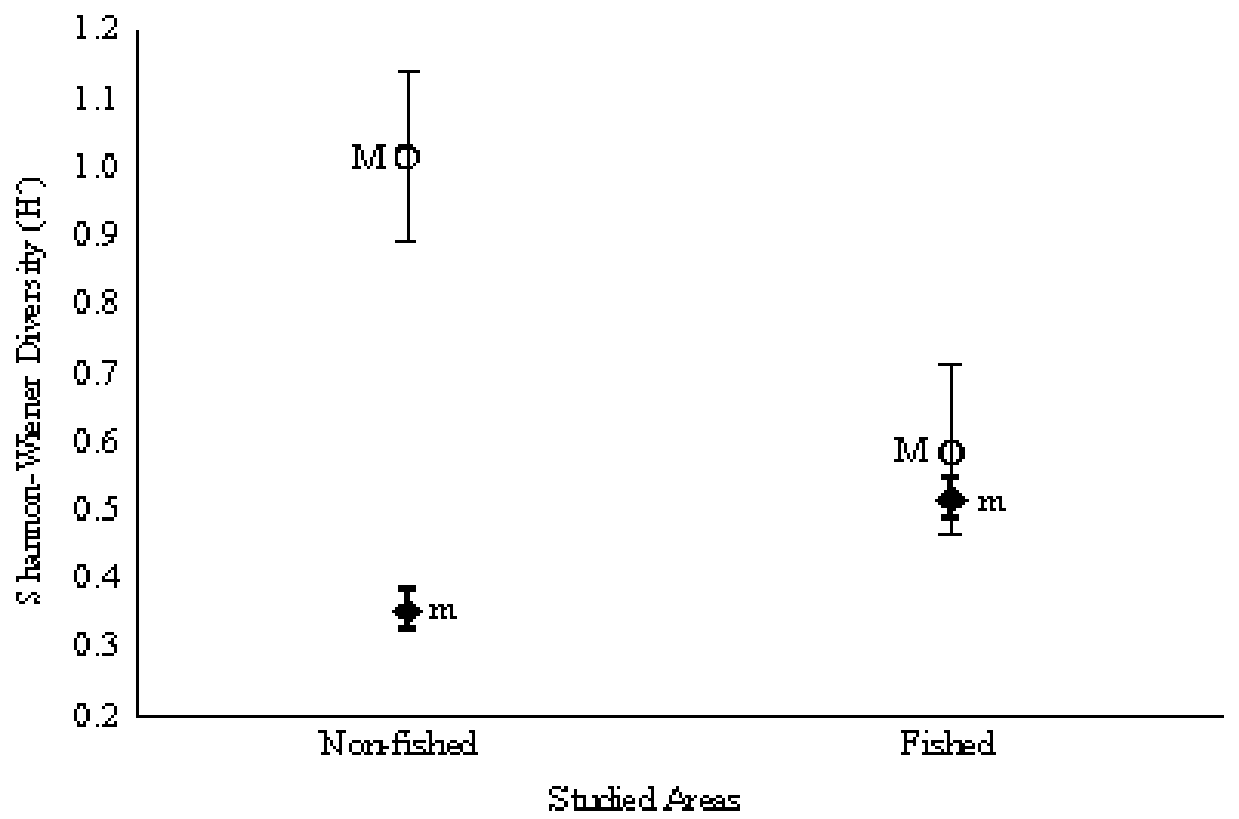

Figure 2. Macrofauna $(\mathrm{M})$ and meiofauna $(\mathrm{m})$ Shannon-Wiener $\left(\mathrm{H}^{\prime}\right)$ diversity calculated for the continuously fished (Vilamoura) and the recently non-fished (Lagos) site. Error bars are standard error. Both macrofauna and meiofauna diversity between sites were significantly different $(P<0.05)$. 
Meiofaunal diversity was higher in the fished area $\left(\mathrm{H}^{\prime}=0.516 \pm 0.093\right)$ than in the non-fished area $\left(\mathrm{H}^{\prime}=0.352 \pm 0.091\right)$, whereas macrofaunal diversity was higher in the non-fished area $\left(\mathrm{H}^{\prime}=1.014 \pm 0.136\right)$ in comparison with the fished area $\left(\mathrm{H}^{\prime}=0.583 \pm 0.137\right)$ (Figure 2). One-way ANOVA results revealed significant differences in meiofaunal $(F(1,22)=18.97 ; P<0.0003)$ and macrofaunal $(F(1,34)=90.028 ; \quad P<0.0001) \quad$ diversity between the two areas. However, no significant differences $(P<0.05)$ were observed between abundance and biomass, for macrofauna and meiofauna, in both areas.

The Bray-Curtis dissimilarity value for the comparison between the fished and recently non-fished areas was $87.82 \%$, as resulted from the SIMPER analysis. The taxa that most contributed to this value were Ampeliscidea, Amphiura mediterranea, Haustoriidae, Nemertinea and Diogenes pugilator (more abundant in the non-fished area) and Spisula solida (more abundant in the fished area). The recently non-fished area was dominated by Ampeliscidea and Amphiura mediterranea, but Haustoriidae, Nemertinea and Diogenes pugilator were also abundant. Spisula solida and Nephtydidae were the most abundant taxa in the continuously fished area (Table 3).

\section{Feeding habits}

In the continuously fished area, total macrofauna suspension-feeders were the most abundant trophic group
(63 ind $\mathrm{m}^{-2}$ ), followed by scavengers $\left(51.04\right.$ ind $\mathrm{m}^{-2}$ ) and herbivores (37.31 ind $\mathrm{m}^{-2}$ ), and deposit-feeders were the least abundant trophic group (24.64 ind $\mathrm{m}^{-2}$ ) (Figure 3). Similarly, deposit-feeders were the least abundant trophic group in the non-fished area (97.92 ind $\mathrm{m}^{-2}$ ), whereas herbivores were the most abundant (308.88 ind $\mathrm{m}^{-2}$ ), followed by suspension-feeders (177.84 ind $\mathrm{m}^{-2}$ ) and scavengers $\left(135.36\right.$ ind $\mathrm{m}^{-2}$ ). There were significant differences between the abundance of herbivores at the two study sites $(F(1,20)=5.623 ; P=0.028)$.

When considering total macrofaunal biomass, the suspension-feeders trophic group was the most important, both at the fished area $\left(27.680 \mathrm{~g} \mathrm{~m}^{-2}\right)$ and the recently non-fished area $\left(29.968 \mathrm{~g} \mathrm{~m}^{-2}\right.$ ) (Figure 4). In the fished area, Vilamoura, the biomass of the other feeding groups were $0.428 \mathrm{~g} \mathrm{~m}^{-2}$ for deposit-feeders, $0.384 \mathrm{~g} \mathrm{~m}^{-2}$ for scavengers, and $0.028 \mathrm{~g} \mathrm{~m}^{-2}$ for herbivores. At Lagos, scavengers represented $3.493 \mathrm{~g} \mathrm{~m}^{-2}$, and deposit-feeders and herbivores contributed with $2.466 \mathrm{~g} \mathrm{~m}^{-2}$ and $0.201 \mathrm{~g}$ $\mathrm{m}^{-2}$ of the total biomass, respectively.

The most abundant meiofaunal trophic group was the deposit-feeders, followed in order by the suspension-feeders, carnivores and herbivores. Depositfeeders total abundance at Lagos and Vilamoura was $696,169.75$ ind $\mathrm{m}^{-2}$ and 315,914 ind $\mathrm{m}^{-2}$, respectively (percentages for each group in Figure 5). However, when considering the biomass of meiofaunal trophic groups, clear differences between Lagos and Vilamoura were

Table 3. Average abundance of macrofauna at the continuously fished (Vilamoura) and the recently non-fished (Lagos) study sites as determined through SIMPER Bray-Curtis dissimilarity calculation.

\begin{tabular}{|c|c|c|c|}
\hline \multirow[b]{2}{*}{ TAXA } & $\begin{array}{c}\text { Fished } \\
\text { (Vilamoura) }\end{array}$ & $\begin{array}{l}\text { Unfished } \\
\text { (Lagos) }\end{array}$ & \multirow[b]{2}{*}{ Cumulative percentage } \\
\hline & \multicolumn{2}{|c|}{ Average abundance } & \\
\hline Ampeliscidea & 0.00 & 11.79 & 10.63 \\
\hline Amphiura mediterranea & 0.67 & 8.93 & 18.99 \\
\hline Haustoriidae & 3.52 & 5.82 & 29.99 \\
\hline Nemertinea & 0.00 & 5.35 & 34.88 \\
\hline Diogenes pugilator & 0.00 & 5.01 & 39.69 \\
\hline Capitellidae & 0.00 & 4.95 & 44.26 \\
\hline Podoceridae & 1.61 & 4.72 & 48.30 \\
\hline Eunicidae & 0.00 & 3.52 & 51.81 \\
\hline Nephtydidae & 3.64 & 3.20 & 55.24 \\
\hline Sipunculo 2 & 0.00 & 3.38 & 58.22 \\
\hline Lysianassidae & 0.67 & 3.25 & 64.14 \\
\hline Apseudes latreillei & 0.00 & 3.36 & 67.00 \\
\hline Cirratulidae & 2.65 & 1.07 & 69.87 \\
\hline Venerupis rhomboides & 0.00 & 3.22 & 72.43 \\
\hline Processa parva & 0.67 & 1.30 & 74.09 \\
\hline Amphictenidae & 0.00 & 1.43 & 75.47 \\
\hline Ophiura texturata & 0.94 & 0.54 & 76.79 \\
\hline Echinocardium cordatum & 0.00 & 0.89 & 78.05 \\
\hline Eurydice pulchra & 0.00 & 1.59 & 79.27 \\
\hline Divaricela divaricata & 0.00 & 1.27 & 80.37 \\
\hline Gibberula miliaria & 0.00 & 1.44 & 81.47 \\
\hline Maldanidae & 0.00 & 1.07 & 82.52 \\
\hline Sipunculo 1 & 0.00 & 1.21 & 83.54 \\
\hline Branchiostoma lanceolatum & 0.67 & 0.44 & 84.55 \\
\hline Chamelea gallina & 0.00 & 0.89 & 85.46 \\
\hline
\end{tabular}




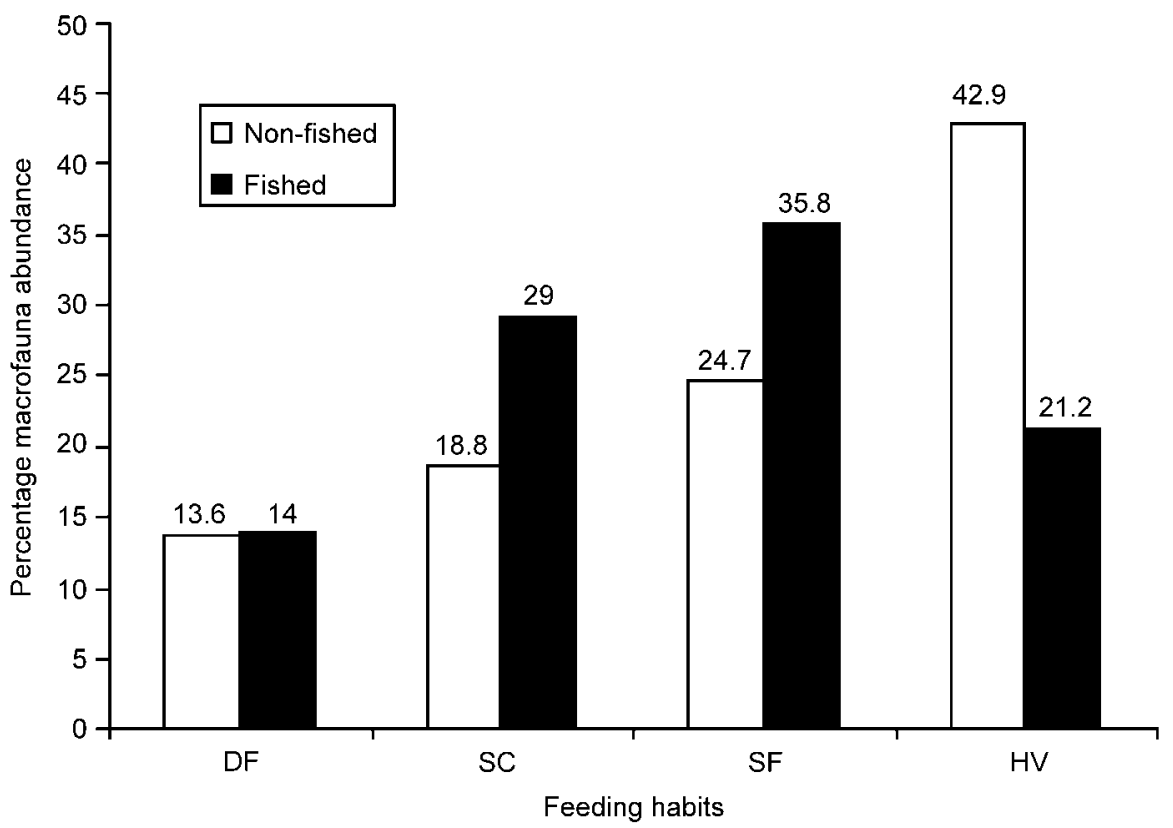

Figure 3. Percentage macrofaunal abundance at the continuously fished (Vilamoura) and the recently non-fished (Lagos) site by major trophic group. DF, deposit-feeder; SC, scavenger; SF, suspension-feeder; HV, herbivore. Error bars are standard error. For calculations purposes taxa were assigned to the most common feeding habit (the first listed, when several indicated, in Table 1). (*significant differences $P<0.05)$.

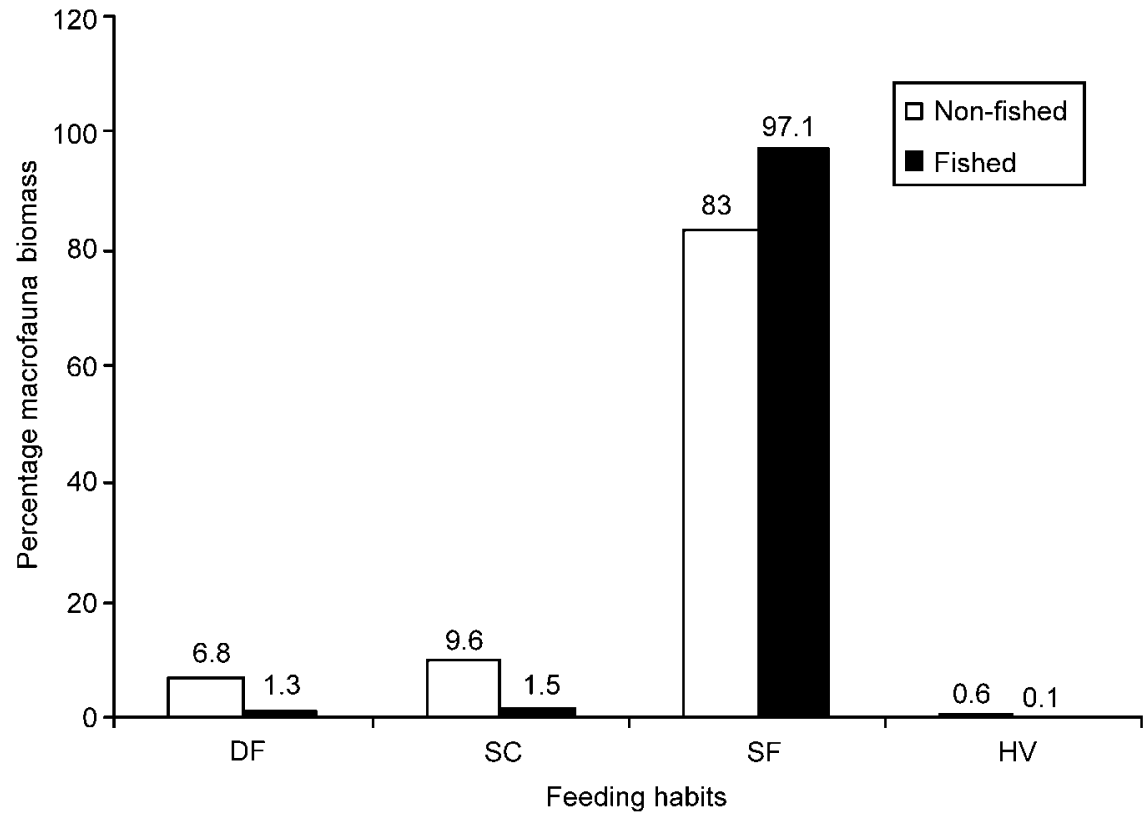

Figure 4. Percentage macrofaunal biomass at the continuously fished (Vilamoura) and the recently non-fished (Lagos) site by major trophic group. DF, deposit-feeder; SC, scavenger; SF, suspension-feeder; HV, herbivore. Error bars are standard error. For calculations purposes taxa were assigned to the most common feeding habit (the first listed, when several indicated, in Table 1).

observed (percentages for each group in Figure 6). Whereas in the recently non-fished area (Lagos) the total biomass of deposit-feeders was $50.122 \mathrm{~g} \mathrm{~m}^{-2}$, at Vilamoura the most important trophic group was the carnivores $\left(1.110 \mathrm{~g} \mathrm{~m}^{-2}\right)$, followed by the depositfeeders $\left(0.029 \mathrm{~g} \mathrm{~m}^{-2}\right)$, herbivores $\left(0.014 \mathrm{~g} \mathrm{~m}^{-2}\right)$ and suspension-feeders $\left(0.006 \mathrm{~g} \mathrm{~m}^{-2}\right)$. At Lagos, carnivores made up $12.88 \mathrm{~g} \mathrm{~m}^{-2}$ of the total biomass, suspensionfeeders $10.009 \mathrm{~g} \mathrm{~m}^{-2}$ and herbivores $0.589 \mathrm{~g} \mathrm{~m}^{-2}$. There were significant differences only between the biomass of deposit-feeders $(F=(1,27)=4.455 ; P=0.044)$ and carnivores $(F=(1,22)=11.412 ; P=0.003)$ at both study sites. 


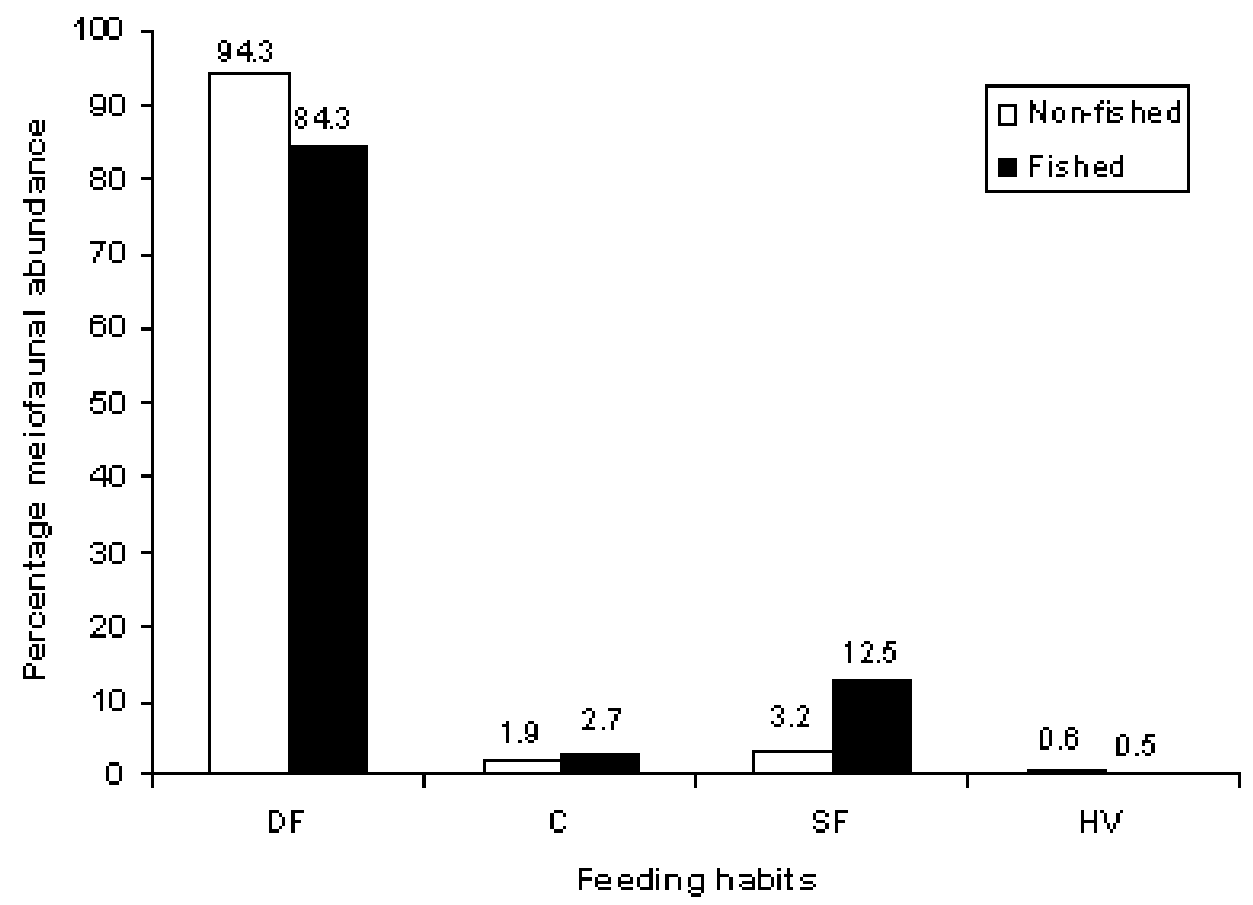

Figure 5. Percentage meiofaunal abundance at the continuously fished (Vilamoura) and the recently non-fished (Lagos) site by major trophic group. DF, deposit-feeder; C, carnivores; SF, suspension-feeder; HV, herbivore. Error bars are standard error. For calculations purposes taxa were assigned to the most common feeding habit (the first listed, when several indicated, in Table 1).

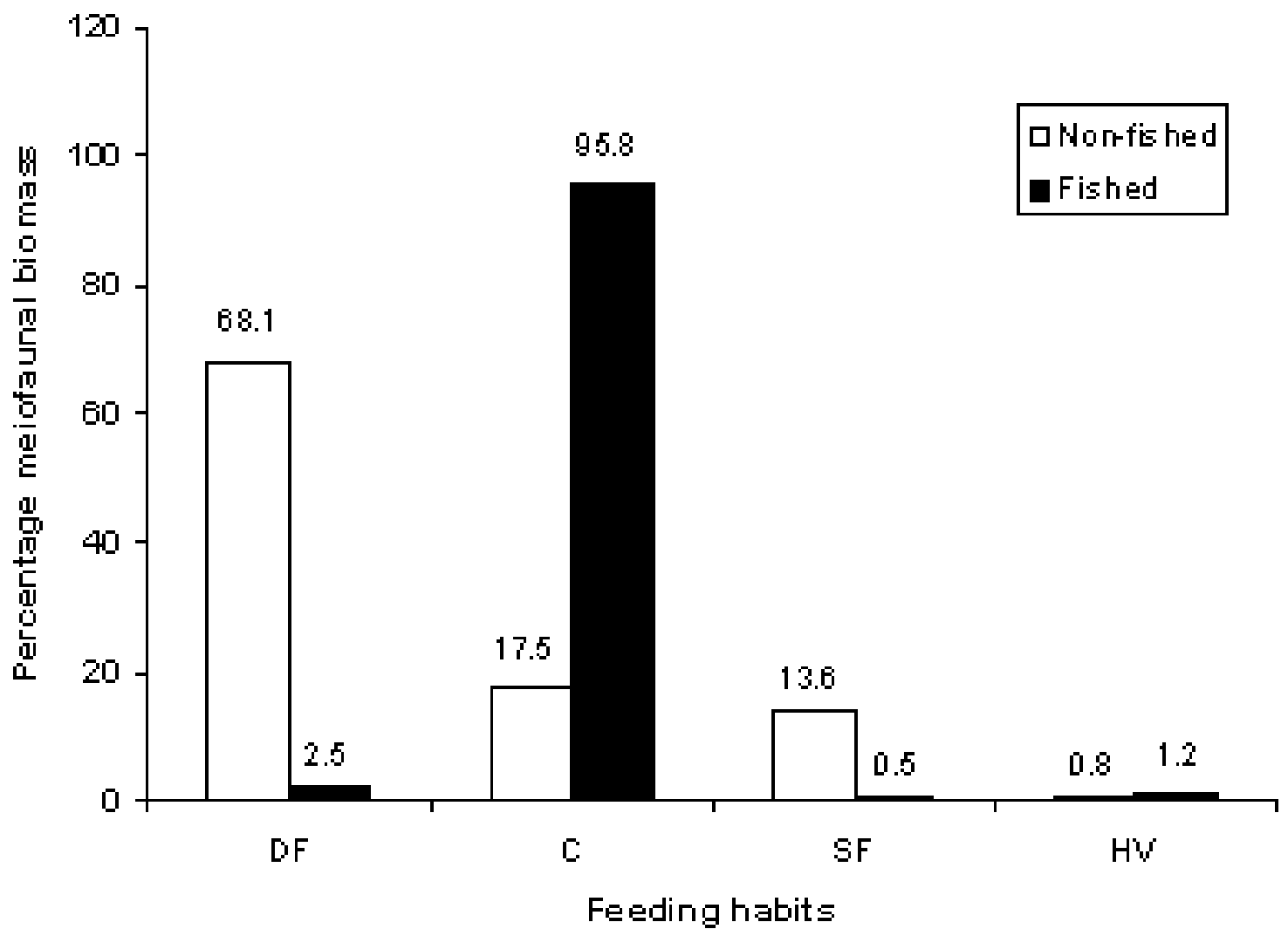

Figure 6. Percentage meiofaunal biomass at the continuously fished (Vilamoura) and the recently non-fished (Lagos) site by major trophic group. DF, deposit-feeder; C, carnivores; SF, suspension-feeder; HV, herbivore. Error bars are standard error. For calculations purposes taxa were assigned to the most common feeding habit (the first listed, when several indicated, in Table 1). 


\section{DISCUSSION}

Changes of abundance, biomass, diversity and dominant trophic groups within macro- and meio-benthic communities were observed between the fished and recently nonfished locations. Macrofauna abundance and diversity were higher in the non-fished area (Lagos). This reduction of these community parameters in the fished area may be attributed to the continuous passage of the dredge teeth on the bottom, damaging and killing mostly macrofauna species that are unable to pass between the teeth. In fact, fragile species like polychaetes, namely Nephtydidae, Nereidae and Cirratulidae, were still very abundant in the fished area. Larger animals, such as the bivalve Acanthocardium tuberculata (more than $60 \mathrm{~mm}$ ) or fragile species like the Nemertinea, Sipunculidae or the sea urchin Echinocardium cordatum, live only at the non-fished area. Thus, the continuous fishing impact in the Vilamoura area probably resulted in a dominance of $r$-selection opportunistic short-lived species such as polychaetes, and a decrease of long-lived sessile species such as sea urchin. Similar observations were described by Commito (1982), Bemvenuti (1994), Rumohr et al. (1998), Mortimer et al. (1999), Christensen et al. (2000) and Jennings et al. (2001).

Biomass of macrofauna species was higher in the fished area, as a result of the abundance of Spisula solida at the area.

Meiofauna in the fished and non-fished area was dominated by Nematoda, Copepoda and Polychaeta. Higher values of abundance and biomass were observed at the recently non-fished area (Lagos). Despite this, ShannonWeiner diversity was lower in this area, owing to the dominance of Nematoda, which represented $90 \%$ of total meiofauna.

Demersal fishing activities provide food for scavengers in the form of damaged animals, which are left in the dredge track (Ramsay et al., 1988). The continuous fishing impact reduced the abundance of herbivores and increased the abundance of suspension-feeders and scavengers, as evidenced by Bray-Curtis dissimilarity results. The larger number of herbivores in the recently nonfished area, mainly amphipods, may be related to the presence of macroalgae that are unable to grow on the impacted area. Abundance of suspension-feeding and scavengers taxa, in the fished site, can be related to the input of organic dead material and to the increase of turbidity caused by the dredge.

Meiofauna are believed to be highly selective feeders with distinct and often highly specialized food niches (Kennedy, 1994). Analysis of meiofauna as a potential indicator of anthropogenic perturbation in aquatic ecosystems has often been limited to monitoring surveys for pollution (Pranovi et al., 2000). However, the meiofauna analysis may also reveal the existence of dredging disturbance, as it seems to occur in this study. In fact, the level of dredging disturbance was the factor that dramatically changed, when the two areas are compared. Both temporal (seasonal) and spatial natural fluctuations of abundance and biomass in both areas, even despite differences that may exist between them, are not expected to justify the magnitude of the changes observed. It may therefore be assumed that the observed differences in this study, in terms of biodiversity, relative abundance and biomass of feeding groups, and in the relation between opportunistic short-lived and long-lived sessile species, can be attributed to the different levels of the fishing impact. Since there are no previous data on the characteristics of the two areas before fishing activity began 40 years ago, we are not able to positively state that the nonfished area has reached its climax. However, observed changes indicate a trend and we would recommend monitoring the Lagos area for a period of two more years before allowing fishing activities. Therefore, based on our results, we anticipate a period of six years for the recovery of the previously fished area. Closing areas for such a long period of time could be a management solution, but difficult to implement due to social and economic pressure by fishermen. An integrated approach, considering the contribution of restocking methods could be useful in allowing a faster recovery of the fishing in impacted communities.

This study was carried out with financial support from the Commission of the European Communities, Agriculture and Fisheries (FAIR) specific RTD programme PL-4465, ECODREDGE. It does not necessarily reflect its views and in no way anticipated the Commissions future policy in this area. Thanks are also due to the EcoResources Group for help with laboratory sample processing, and to IPIMAR/CRIPsul for logistical support.

\section{REFERENCES}

Banse, K., 1982. Mass-scale rates of respiration and intrinsic growth in very small invertebrates. Marine Ecology Progress Series, 9, 281-297.

Bemvenuti, C.E., 1994, O poliqueta Nephtys fluviatilis Monro, 1937, como predador da infauna na comunidade de fundos moles. Atlântica, Rio Grande, 16, 87-98.

Bradshaw, C., Veale, L.O., Hill, A.S. \& Brand, A.R., 1999. The effects of scallop dredging on Irish Sea benthos: experiments using a closed area. Fournal of Shellfish Research, 18, 709.

Caddy, J.F., 1973. Underwater observations on tracks of dredges and trawls and some effects of dredging on a scallop ground. Fournal of the Fisheries Research Board of Canada, 30, 173-180.

Chícharo, L.M., Chícharo, M.A., Alves, F. \& Regala, J., 2000. Ecological analysis of dredge impact on the south of Portugal. Ecodredge Project (FAIR PL-4465) Interim Report, 39 pp.

Christensen, B., Vedel, A. \& Kristensen, E., 2000. Carbon and nitrogen fluxes in sediment inhabited by suspension-feeding (Nereis diversicolor) and non-suspension-feeding (N. virens) polychaetes. Marine Ecology Progress Series, 192, 203-217.

Clarke, K.R. \& Warwick, R.M., 1994. Changes in marine communities: an approach to statistical analysis and interpretation. Natural Environment Research Council: Bourne Press Limited.

Commito, J.A., 1982. Importance of predation by infaunal polychaetes in controlling the structure of a soft-bottom community in Maine, USA. Marine Biology, 68, 77-81.

Commito, J.A. \& Shrader, P.B., 1985. Benthic community response to experimental additions of the polychaete Nereis virens. Marine Biology, 68, 101-107.

Conner, W.G. \& Simpson, J.L., 1979. The effects of oyster shell dredging on an estuarine benthic community. Estuarine and Coastal Marine Science, 9, 749-758.

Currie, D.R. \& Parry, G.D., 1996. Effects of scallop dredging on a soft sediment community: a large scale experimental study. Marine Ecology Progress Series, 134, 131-150.

Currie, D.R. \& Parry, G.D., 1999. Impacts and efficiency of scallop dredging on different soft substrates. Canadian Fournal of Fisheries and Aquatic Sciences, 56, 539-550.

Daget, J., 1979. Les modèles mathématiques en écologie. 3ème ed. Paris: Masson. 
Dare, P.J., Key, D. \& Connor, P.M., 1993. The efficiency of spring-loaded dredges used in the western English Channel fishery for scallops, Pecten maximus (L.). International Council for the Exploration of the Sea, Fish Capture Committee (CM Papers and Reports), CM 1993/B:15 (Ref. K), 8 pp.

Dias, J.M.A., 1987. Dinâmica sedimentar e evolução recente da plataforma continental portuguesa setentrional. $\mathrm{PhD}$ thesis, Universidade de Lisboa, Lisboa, Portugal.

Downing, J., 1989. Precision of the mean and the design of benthos sampling programmes: caution revised. Marine Biology, 103, 231-234.

Eleftheriou, A. \& Robertson, M.R., 1992. The effects of experimental scallop dredging on the fauna and physical environment of a shallow sandy community. Netherlands Journal of Sea Research, 30, 289-299.

Elliot, J.M., 1977. Some methods for statistical analysis of samples of benthic invertebrates. Scientific Publications Freshwater Biology Association, 25, $156 \mathrm{p}$.

Feder, D.H., 1981. Aspects of the feeding biology of the brittle star Ophiura texturata. Ophelia, 20, 215-235.

Fish, J.D. \& Fish, S., 1996. A student's guide to the seashore. Cambridge: Cambridge University Press.

Fiúza, A.F., 1983. Upwelling patterns off Portugal. In Coastal upwelling: its sediment record. Part A: responses of the sedimentary regime to present coastal upwelling (ed. E. Suess and J. Thiede), pp. 175-197. New York: Plenum Press.

Frid, C.L.J., Clark, R.A. \& Haal, J.A., 1999. Long-term changes in the benthos on a heavily fished ground off NE coast of England. Marine Ecology Progress Series, 188, 13-20.

Gamito, S., 1994. The benthic ecology of some Ria Formosa lagoons, with reference to the potential for production of the gilhead seabream (Sparus aurata, L.). PhD thesis, Universidade do Algarve, Faro, Portugal.

Gaspar, M.B., 1996. Bivalves do litoral oceânico algarvio. Aspectos da biologia, ecologia e da pescaria dos mananciais de interesse económico: aplicação à gestão dos recursos. $\mathrm{PhD}$ thesis, Universidade do Algarve, Faro, Portugal.

Gilkinson, K.D. et al., 1999. Impacts of otter-trawling on infaunal bivalves living in sandy bottom habitats on the Grand Banks of Nerefoundland. Abstract Book, ICES/SCOR SymposiumEcosystem effects of fishing. Montpellier, France-15-19 March 1999, 34 pp.

Groot, S. de, 1984. The impact of bottom trawling on benthic fauna of the North Sea. Ocean Management, 9, 177-190.

Hall, S.J., Robertson, M.R., Basford, D.J. \& Heaney, S.D., 1993. The possible effects of fishing disturbance in the northern North Sea: an analysis of spatial patterns in community structure around a wreck. Netherlands Fournal of Sea Research, 31, 201-208.

Hall-Spencer, J.M. \& Moore, P.G., 2000. Scallop dredging has profound, long-term impacts on maerl habitats. ICES Journal of Marine Science, 57, 1407-1415.

Jennings, S. \& Kaiser, M.J., 1998. The effects of fishing on marine ecosystems. Advances in Marine Biology, 34, 201-351.

Jennings, S., Pinnegar, J.K., Polunin, N.V.C. \& Warr, K.S., 2001. Impacts of trawling disturbance on the trophic structure of benthic invertebrate communities. Marine Ecology Progress Series, 213, 127-142.

Kaiser, M.J., Edwards, D.B., Armstrong, P.A., Radford, K., Lough, N.E.L., Flatt, R.P. \& Jones, H.D., 1998. Changes in megafaunal benthic communities in different habitats after trawling disturbance. ICES Fournal of Marine Science, 55, 353-361.

Kaiser, M.J. \& Spencer, B.E., 1996. The effects of beam-trawl disturbance on infaunal communities in different habitats. Fournal of Animal Ecology, 65, 1-25.
Kennedy, A.D., 1994. Predation within meiofaunal communities: description and results of a rapid-freezing method of investigation. Marine Ecology Progress Series, 114, 71-79.

Knox, G.A, 1986. Estuarine ecosystems: a systems approach, vols. 1 and 2. Florida: CGR Press Inc.

Lindeboom, H.J. \& Groot, S.J. de, 1998. The effects of different types of fisheries on the North Sea and Irish Sea benthic ecosystems. IMPACT-II, NIOZ-Rapport, $404 \mathrm{pp}$.

McKillup, S.C. \& McKillup, R.V., 1994. The decision to feed by a scavenger in relation to the risk of predation and starvation. Oecologia, 97, 41-48.

Moita, I., 1986. Plataforma continental. Carta dos sedimentos superficiais. Notícia explicativa da folha SED 7 e 8. Instituto Hidrografico (Relatório), 18 pp.

Mortimer, R.J.G., Davey, J.T., Krom, M.D., Watson, P.G., Frickers, P.E. \& Clifton, R.J., 1999. The effect of macrofauna on porewater profiles and nutrient fluxes in the intertidal zone of the Humber Estuary. Estuarine, Coastal and Shelf Science, 48, 683-699.

Pranovi, F., Raicevich, S., Franceschini, G., Farrace, M.G. \& Giovanardi, O., 2000. Rapido trawling in the northern Adriatic Sea: effects on benthic communities in an experimental area. ICES fournal of Marine Science, 57, 1-8.

Ramsay, K., Kaiser, M.J. \& Hughes, R.N., 1998. Responses of benthic scavengers to fishing disturbance by towed gears in different habitats. Fournal of Experimental Marine Biology and Ecology, 224, 73-89.

Rield, R., 1986. Fauna y flora del mar Mediterráneo. Barcelona, Spain: Ediciones Omega, S.A.

Rumohr, H., Ehrich, S., Knust, R., Kujawski, T., Philippart, C.J.M. \& Schroeder, A., 1998. Long-term trends in demersal fish and benthic invertebrates. In The effects of different types of fisheries on the North Sea and Irish Sea benthic ecosystems, NIOZRapport 1998-1/Rivo-Dlo Report C003/98 (ed. H.J. Lindeboom and S.J. de Groot), pp. 280-352.

Skoeld, M. \& Rosenberg, R., 1996. Arm regeneration frequency in eight species of Ophiuroidea (Echinodermata) from European sea areas. Fournal of Sea Research, 35, 353-362.

Sprung, M., 1993. Estimating macrobenthic secondary production from body weight and biomass: a field test in a non-boreal intertidal habitat. Marine Ecology Progress Series, 100, 103-109.

Sprung, M., 1994a. Macrobenthic secondary production in the intertidal zone of the Ria Formosa - a lagoon in southern Portugal. Estuarine, Coastal and Shelf Science, 38, 539-558.

Sprung, M., 1994b. High larval abundance in the Ria Formosa - a lagoon in southern Portugal - methodological or local effects? Fournal of Plankton Research, 16, 151-160.

Teixeira, S.B., 2000. Lithology of beach gravel in central Algarve (Portugal). In Proceedings of the 3rd Symposium on the Iberian Atlantic Continental Margin, Faro (ed. J.M.A. Dias and O. Ferreira), pp. 139-141. Universidade do Algarve, Portugal: Ciacomar.

Tuck, I., Ball, B. \& Schroeder, A., 1998. Comparison of undisturbed and disturbed areas. In The effects of different types of fisheries on the North Sea and Irish Sea benthic ecosystems NIOZRapport 1998-1/Rivo-Dlo Report C003/98, 404pp. (ed. H.J. Lindeboom and S.J. de Groot), pp 245-280.

Veniza, A.F., 1988. Sampling variance and the design of quantitative surveys of the marine benthos. Marine Biology, 97, 151-155.

Vieira, N., Mateus, M. \& Coelho, H., 2000. Temperature, salinity and geostrophic distributions in the Iberian Atlantic Margin. In Proceedings of the 3rd Symposium on the Iberian Atlantic Continental Margin, Faro (ed. J.M.A. Dias and O. Ferreira), pp. 151-153. Universidade do Algarve, Portugal: Ciacomar.

Submitted 14 March 2001. Accepted 22 October 2001. 